\title{
Review on Determinants of Corporate Bond Spread on the Basis of Liquidity Risk
}

\author{
Jiemin Huang \\ Shenzhen Institute of Information Technology 2188 Longxiang Boulevard, Longgang District \\ Shenzhen City, People's Republic of China, 086-518172 \\ huang_jiemin819@126.com
}

Keywords: Corporate bond spreads; Bond age; Liquidity risk

\begin{abstract}
The scholars have analyzed the determinants of corporate bond spreads from the individual factors, and the company's primary liquidity risk analysis on the bonds term, age and so on. Some scholars as the missing variable liquidity risk, it was found to explain a small portion of investment grade bond spreads. We will review on the literature of corporate bond spread about liquidity risk, and will find the blank of their research. China bond market is maturing, but the Exchange corporate bond market is not mature enough, compared with European and American countries, China illiquid corporate bonds, and thus there is a big liquidity risk premium.
\end{abstract}

\section{The Domestic and Foreign Research Analysis}

Ericsson and Renault (2005), Longstaff et al (2005), Chen et al (2007), Acharya, Pedersen (2005) considered not only to consider when pricing the asset liquidity level should also consider liquidity risk [1-2]. However, Acharya et al (2008) believe there are not more [3]. This is not conclusive evidence, because these studies are from indirect government bonds and stocks come on liquidity. Dick-Nielsen et al. (2012) used several different methods to measure the level of liquidity, including the use of these volatile measure of volatility to represent liquidity risk, in order to test their contribution to corporate bond spreads [3]. They concluded that, in normal times, liquidity risk can only explain a small part of the investment grade bond spreads, and the economic crisis, was able to explain much of spreads.

Perraudin (2003) will represent liquid bond data classification, including the frequency of quotations, bond issuance and age, studies show that the liquidity risk premium is an important part of the spread. He found that for high-grade credit bonds spreads its liquidity risk premium than others [4]. Houweling (2005) Liquidity risk Liquidity proxy variable used, there are nine liquidity proxy variables: circulation, whether listed, just released, the bond age, loss of price, yield volatility, the number of bonds purchased and income dispersion. He used four-variable model to control interest rate risk, maturity and credit rating. The results rejected the corporate bond prices do not include liquidity risk of the null hypothesis, nine eight proxy variables significantly [5].

Acharya (2010) studied on 1973 - Year 2007 Fluidity corporate bonds and stocks and bonds [2]. Stocks or bonds weakened liquidity conflict effect: When the speculative grade bond prices fall, investment-grade bond prices. The impact of dynamic changes at any time, when the economy is in a downturn, this effect is sustained. Possibility in this period can be associated with adverse economic conditions related to the macroeconomic variables and financial market variables to predict. His model can predict the economic downturn in 2008 - 2009 bond yields outside the sample. After controlling for other systematic risk (duration and default), these effects are still strong. Their studies showed that the presence of corporate bonds varies with time liquidity risk. Dick-Nielsen (2010) studied the use of illiquid corporate bonds before and after the financial crisis of liquidity. The study found that during the financial crisis, the illiquid bonds significantly increased bond spreads continued to slowly increase. When the financial crisis first company to issue bonds guarantor severely affected, bond liquidity becomes worse, financial bonds issued by the Company during the financial crisis and even stop the flow [6].

Bongaerts (2011) use a balanced asset pricing model to study and joined the company liquidity 
risk, derivatives for hedging and risk-free trading of short positions. He proved that if holders of short positions have more assets, non-current assets have a lower expected return, lower risk aversion, or lower levels of risk aversion. For derivatives pricing and liquidity risk for positive liquidity risk pricing net asset different from the former reliance on non-trading investors to take risks. He used this model credit default swaps market. He found that the credit protection seller will win the expected liquidity premium. The role of liquidity risk is very important but little impact on the economy [7].

Section Data Pricing liquidity risk corporate bonds Lin (2011) by January 1994 to March 2009 period. Liquidity highly sensitive bond than the average annual income of low liquidity in high-sensitive bonds average yield of $4 \%$. Bond was positively correlated with the expected return of liquidity $\beta$, and for breach of contract, period $\beta$, liquidity and other bonds as well as features for different flow measurement methods, positive relationship between the two are strong. The results show that liquidity risk is an important factor in the expected corporate bonds. The recent global financial crisis has demonstrated the important role of internal liquidity risk for credit risk, however, few studies its impact on bond yields spreads [8].

Chen (2011) use 1993-2008 panel data, and found that the control bond yields decision variables, measure traditional methods companies' ability to repay debt, and cash flow volatility, credit rating and state variables, internal liquidity risk bond yields spreads have a major impact. The results show that internal liquidity risk should be included in the bond yield spread model [9]. Friewald (2012) found that in the US corporate bond market liquidity is an important factor in the price. He studied during the financial crisis of liquidity if more pronounced. He has chosen the only bond of more than 20,000 in October 2004 to December 2008 period. He found that the liquidity impact of the company's bond spreads $14 \%$. He believes that for speculative-grade bonds, in times of economic crisis, greater fluidity of [10].

Wang (2008) with a generalized model of liquidity risk liquidity, default and personal income tax on bonds and municipal bond yields. Empirical studies show that municipal bond yields are strongly influenced by three factors. Effect of default and liquidity risks to municipal bond yields increased with maturity and credit risk increases. A large part of the long maturity municipal bonds with short maturity municipal bond spreads are liquidity premium. Does not consider liquidity risk can lead to serious underestimation of municipal bond yields. In considering the impact of tax and default risk conditions, he found that high personal income tax rates and institutional investors with the implied personal income tax rate is close. The results prove that contain liquidity risk municipal bonds may help explain the mystery of the municipal bond [11].

Kagraoka (2010) on the corporate bond yield spread impact panel data time series study of risk factors. That risk premium system. Analysis system risk premium to the credit risk and liquidity risk assessment; credit risks assessed by credit rating, liquidity risk through indirect measurement of the difference in income brokerage firm quote. Some scholars have used this model to test the Japanese corporate bond market. The empirical results show that changes over time can be estimated with a risk factor of credit risk and liquidity risk out [12].

Domestic scholars on liquidity and more concentrated in a review and qualitative analysis, quantitative research is very small. Renzhao Zhang (2006) based on the establishment of a liquidity risk of default can bond pricing model of credit spreads default risk and liquidity risk were separated to obtain liquidity and risk-adjusted pricing of credit default swaps on this basis. He estimated considering the liquidity risk and liquidity risk to ignore the strength of default parameters and calculate the exchange price at this time [13]. He Zhigang (2012) using data in April 2007 to September 2009, the analysis in the sub-prime crisis affect liquidity risk on corporate bond spreads, he used illiquid method, empirical results significantly, and robust [14 ].

Li Xiaoqing (2008) using data based on daily data and the inter-bank bond market transactions, is calculated using the method to verify the impact of the trading mechanism and constantly improve the liquidity of the market, the results show that market makers, open repo, forward transactions Securities lending and implemented to some extent, increased market liquidity, but the measurement results are not significant. The company has a bond investment risk, according to the 
theory of risk diversification, portfolio consisting of a number of securities, the proceeds of the weighted average of these bond yields. In order to effectively avoid risks, maximize revenue, may take the following methods: First, the term dispersion method, ie bonds yield to maturity of bonds in different; second, geographic dispersion, bond investments in a number of areas of the enterprise, reduce because the risks of a regional recession; third, industry dispersion method, the investment in bonds of different industries, some industries because of natural conditions, consumer demand and other factors, the bond yields will fall.

Hanbao Zhen (2010) by constructing turnover, slope, credit and bond credit rating and the maturity date, including the "five-factor model" to analyze data in recent years, the Shanghai and Shenzhen exchanges, analysis of different corporate bond liquidity risk premium, the results show that the stronger liquidity, liquidity risk premium is smaller, the liquidity of corporate bonds overall difference is not so different liquidity risk premiums of corporate bonds is relatively small [15]. Wang Yi (2011) on the corporate bond market liquidity measurement methods to summarize the existing liquidity from the corporate bond spreads measuring method based on the transaction price impact on measurement method, measurement method based on bond characteristics and the implicit flow four aspects of the sort and analysis [16].

Many scholars on mobility were studied. Amihud and Mendelson (1986) considered because there are different types of investors [17], the transaction cost is the cause of equilibrium asset prices generate liquidity premium, which is the main research stock market Amihud, Mendelson, and Pedersen (2006) [18]. In the OTC market, Duf fi e, Garleanu, and Pedersen (2007) prove that the transaction costs due to the presence of search costs, inventory costs and bargaining power generated [19], Jankowitsch, Nashikkar, and Subrahmanyam (2011) similar to their studies [ 20].

Some scholars have studied the corporate bond yield, or yield spread liquidity impact. These studies will be characterized bonds as indirect proxy variables such as: coupon rate, age, circulation, trade and terms of the bond. Some scholars use proxies for market-related according to trading activities, such as: trading volume, turnover, traders volume and bid-ask spread Liu, Longstaff and Mandell (2004), De Jong and Driessen (2006), Edwards, Harris and Piwowar (2007). They have found that bond yields are included in liquidity factors [21-22].

\section{Review}

Study on bond liquidity on corporate bond yield spread influence. The main advantage of foreign scholars equilibrium model and structural model for liquidity risk premium, because the liquidity risk cannot be measured directly, indirectly measured by the need for other agents variables, some scholars choose dozen proxy for measuring liquidity risk Liquidity risk, they the study shows that the liquidity risk premium occupies an important position in the corporate bond spreads. Some scholars also found that liquidity risk has an important influence on the pricing of corporate bonds and derivatives pricing, but they believe that liquidity risk is not important. Some scholars also internal liquidity risk, and found that it should be included in the corporate bond yield spread. An Empirical Study of liquidity risk domestic scholars mainly from the pricing of bonds and non-liquidity. There are a number of qualitative researches and a review of the nature, very little quantitative research. This paper selects five proxies for liquidity, using empirical methods to analyze the impact of liquidity risk corporate bond yield spreads.

\section{References}

[1] Longstaff F, Mithal S, Neis E. Corporate yield spreads: default risk or liquidity? [J]. Journal of Finance, 2005, 60: 2213-2253.

[2] Chen L, Lesmond D, Wei J. Corporate yield spreads and bond liquidity [J]. Journal of Finance, 2007, 62: 119-149.

[3] Acharya V, Pedersen L. Asset pricing with liquidity risk [J]. Journal of Financial Economics, 2005, 77: 375-410. 
[4] Acharya V, Amihud Y, Bharath S. Liquidity risk of corporate bond returns [EB/OL]. http://www.nber.org/papers/w16394.pdf?new_window=1, 2008

[5] Dick-Nielsen J, Feldhuetter P, Lando D. Corporate bond liquidity before and after the onset of the subprime crisis [J]. Journal of Financial Economics, 2012, 103: 471-492.

[6] Perraudin W R, Taylor A P. Liquidity and bond market spreads [EB/OL]. https://papers.ssrn.com/sol3/Data_Integrity_Notice.cfm?abid=424060, 2003

[7] Houweling P, Mentink A, Vorst T. Comparing possible proxies of corporate bond liquidity [J]. Journal of Banking \& Finance, 2005, 29: 1331-1358.

[8] Dick N J, Feldhutter P, Lando D. Corporate bond liquidity before and after the onset of the subprime crisis [J]. Journal of Financial Economics, 2010, 103: 471-492.

[9] Bongaerts D, Jong F D, Driessen J. Derivative Pricing with Liquidity Risk: Theory and Evidence from the Credit Default Swap Market [J]. Journal of finance, 2011, 6: 203-240.

[10] Lin H, Wang J, Wu C. Liquidity risk and expected corporate bond returns [J]. Journal of Financial Economics, 2011, 99: 628-650.

[11] Chen T K, Liao H H, Tsai P L. Internal liquidity risk in corporate bond yield spreads [J]. Journal of Banking \& Finance, 2011, 35: 978-987.

[12] Friewald N, Jankowitsch R, Subrahmanyam M G. Illiquidity or credit deterioration: A study of liquidity in the US corporate bond market during financial crises [J]. Journal of Financial Economics, 2012, 105: 18-36.

[13] Wang J, Wu C, Zhang F X. Liquidity, default, taxes, and yields on municipal bonds [J]. Journal of Banking \& Finance, 2008, 32: 1133-1149.

[14] Kagraoka Y. A time-varying common risk factor affecting corporate yield spreads [J]. European Journal of Finance, 2010, 16(6): 527-539.

[15] Zhao-zhang ren, li peng. China's corporate bond spreads individuality an empirical analysis of the factors affecting [J]. Journal of south China university of technology (social science edition), 2006, 8:52-55.

[16] Zhi-gang he Shao Ying. Liquidity risk of our country corporate bond credit spreads - based on the influence of the subprime crisis background research [J]. Journal of accounting and economic studies, 2012, 1:78-85.

[17] Xiao-qing Li. Trading mechanism and an empirical analysis of the inter-bank bond market liquidity [J]. Journal of financial review, 2008, 93-95.

[18] Han Baozhen. China corporate bond exchange market liquidity premium empirical study [J]. Journal of zhengzhou aviation industry management institute, 2010, 28:78-81.

[19] Wang xiao bo. The corporate bond market liquidity measure review [J]. Journal of tangshan college, 2011, 24:53-55.

[20] Amihud Y, Mendelson H. Asset pricing and the bid-ask spread. Journal of Financial Economics [J]. 1986, 17: 223-249.

[21] Amihud Y, Mendelson H, Pedersen L H. Liquidity and asset prices [J]. Foundations and Trends in Finance, 2006, 1: 269-364.

[22] Duffie D, Garleanu N, Pedersen L H. Valuation in over the counter markets [J]. Review of Financial Studies, 2007, 20: 1865-1900. 